\title{
Distribution extension of Aspiculuris americana parasite of Peromyscus difficilis in Hidalgo, México
}

\author{
Griselda Pulido-Flores' ${ }^{1}$, Scott Monks ${ }^{1}$ and Jorge Falcón-Ordaz ${ }^{*}$ \\ 1 Universidad Autónoma del Estado de Hidalgo, Centro de Investigaciones Biológicas, Apdo. Postal 1-69, C.P. 42001, Pachuca. \\ Hidalgo, México. Email: gpulido@uaeh.edu.mx (GPF), smonks@uaeh.edu.mx (SM), jfalcon.ordaz@gmail.com (JFO). \\ ${ }^{*}$ Corresonding autor
}

\begin{abstract}
As a part of an ongoing project to inventory the helminth parasites of rodents in México, 30 individuals of Aspiculuris americana were collected inhabiting the intestine from three specimens of the rock mouse Peromyscus difficilis, collected from Cerro Xihuingo, Municipality of Tepeapulco, Hidalgo State, México. This species of nematode parasite different species of the genus Peromyscus ( $P$. gossypinus, $P$. leucopus, $P$. maniculatus, and P. floridanus) distributed from Yukon Territory in Canada to Florida in the United States of America. This is the first report of Aspiculuris americana in a Mexican endemic rodent, widening the known distribution of the species to the southern portion of the country.

Como parte de un proyecto para inventariar los parásitos helmintos de roedores en México, se recolectaron 30 individuos de Aspiculuris americana que parasitan el intestino de tres especímenes del ratón de las rocas Peromyscus difficilis, recolectados en Cerro Xihuingo, Municipio de Tepeapulco, Estado de Hidalgo, México. Esta especie de nematodo parasita diferentes especies del género Peromyscus (P. gossypinus, P. leucopus, P. maniculatus y P. floridanus) distribuidas desde el territorio de Yukon en Canadá hasta Florida en los Estados Unidos de América. Este es el primer informe de Aspiculuris americana en un roedor endémico mexicano, ampliando la distribución conocida de la especie a la parte sur del país.
\end{abstract}

Key words: Geographic distribution; helminth fauna; rodent; taxonomy.

C 2019 Asociación Mexicana de Mastozoología, www.mastozoologiamexicana.org

\section{Introduction}

The Rock Mouse, Peromyscus difficilis is a Mexican endemic cricetid rodent, distributed from southwestern Chihuahua and southeastern Coahuila to north-central Oaxaca, including the states of Durango, Zacatecas, San Luis Potosí, Guanajuato, México, Puebla, Hidalgo, Tlaxcala, Veracruz, and Oaxaca (Fernandez et al. 2010). This rodent species has been studied for helminths in México since 1990, being his helminthological record two Trematodes (Brachylaimidae gen. sp. and (aballerolecythus ibunami), five Cestodes (Catenotaenia peromysci, Dilepididae gen. sp., Hymenolepis diminuta, Rodentolepis sp., and Taenia pisiformis) and eight Nematodes (Aspiculuris sp., Carolinensis huehuetlana, Syphacia sp., Stilestrongylus peromysci, Vexillata vexillata, Protospirura mexicana, Calodium hepaticum and Trichuris fossor) (see García-Prieto et al. 2012; Falcón-Ordaz et al. 2015).

In Hidalgo State, the genus Aspiculuris Schulz, 1924 has been found parasitizing Mus musculus (A. cf. lahorica and A. huascahensis) from Metztitlán and Huasca de Ocampo, and Peromyscus difficilis (Aspiculuris sp.) from Tepeapulco (Falcón-Ordaz et al. 2015). Aspiculuris are parasites of Muroidea (Rodentia); currently includes 21 nominal species (Arya 1980; Manna et al. 1985; Liu et al. 2012) distributed worldwide (Goswami et al. 2015). In México has been registered in Neotoma mexicana (García-Prieto et al. 2012). The main goal of this report is to add one nematode species to the helminth fauna of this host species: Aspiculuris americana Erickson, 1938 infecting an endemic rodent of central México.

\section{Materials and Methods}

On March 2009, three specimens of $P$. difficilis were caught under permit FAUT-0217 (issued to S. Monks) from Cerro Xihuingo ( $\left.19^{\circ} 48^{\prime} 05.9^{\prime \prime} \mathrm{N},-98^{\circ} 32^{\prime} 30.1^{\prime \prime} \mathrm{W}\right)$, Municipality of Tepeapulco, Hidalgo, México 2,511 masl. The collecting and processing of rodents follows the guidelines of the American Society of Mammalogists for use of wild animals in research (Kelt et al. 2010; Sikes and The Animal Care and Use Committee of the America Society of Mammalogists 2016). The intestine of hosts was examined for helminths under microscope; nematodes recovered were washed in $0.85 \%$ saline solution, and fixed in $4 \%$ hot formalin. For morphologic study, nematodes were cleared with Amman's lactophenol. All measurements are given in micrometers $(\mu \mathrm{m})$ unless otherwise indicated. Measurements are registered as the range followed by the mean and standard deviation in parentheses. For scanning electron microscopy (SEM) study, nematodes were dehydrated in series of gradual ethyl alcohol and critical point dried with carbon dioxide. Specimens were coated with a gold-palladium mixture and examined in a Hitachi S-2460N scanning electron microscope at $15 \mathrm{kV}$. Also, we consult specialized literature and available databases of the Harold W. Mantter Laboratory (HWML), Museum of Southwestern Biology (MSB) and United States National Museum (USNM) to know the current distribution of Aspiculuris and its hosts. Parasite voucher specimens were deposited at Colección Nacional de Helmintos (CNHE), Instituto de Biología, Universidad Nacional Autónoma de México (IBUNAM), México City. 


\section{Results}

Aspiculuris americana. Description based on 30 specimens (13 males and 17 females) identified as A. americana (CNHE 10945) recovered from the caecum of one specimen of $P$. difficilis. This species is characterized by the following traits: medium size, stout nematodes. Cervical alae abruptly interrupted, forming an acute angle, ending beyond of esophageal bulb (Figure 1b). Mouth surrounded by six lips, one pair of lateral "epaulettes" with two amphids, and four labial papillae (Figure 1a). Male possesses one pairs of caudal alae (Figures $1 \mathrm{c}, \mathrm{d}$ ).
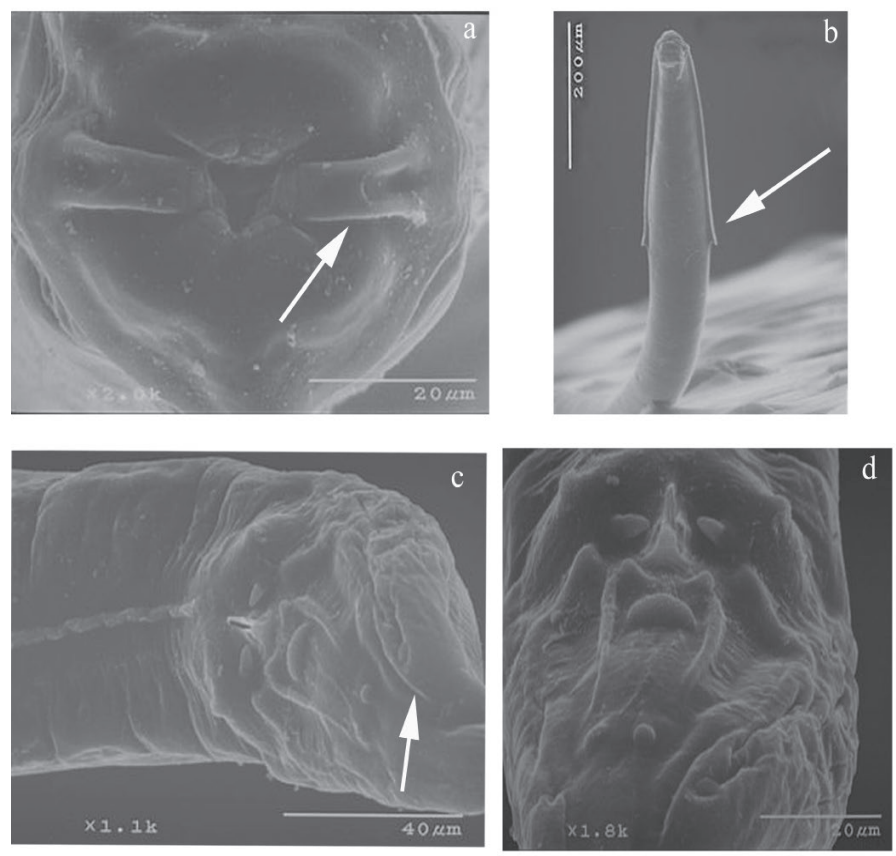

Figure 1: Aspiculuris americana male, a). Mouth, apical view showing the "epaulettes". b). Anterior end, ventral view showing cervical alae. c). Posterior end wiew showing the caudal alae. d). Detail of caudal papillae.

Male: Cephalic inflantion present. Esophagus bulb with form elliptical. Nerve ring anterior to mid-esophagus (Figure 2a). Excretory pore in the anterior third of the body. In a, cross section of the body, the cervical and lateral alae have two crest (Figure $2 \mathrm{c}$ ) and in the middle of the body they lack alae (Figure $2 \mathrm{~d}$ ). A ventral ala is present in males, beginning at the mid-body region and ending before the cloaca (Figures 1c, 2e). The 12 caudal papillae are arranged in the following manner: one pair precloacal close to margin of cloaca, one pair of adcloacal papilliform formations, a single medial postanal closely associated with cloaca, two pairs postcloacal, followed by one single median (located between two long and straight cuticular thickenings), one subventral pair midway between cloaca and end of tail (Figures 1c, d, 2b). Measurements are given in Table 1.

Female: Cephalic inflantion present. Esophagus bulb with form elliptical. Nerve ring anterior to mid-esophagus. Excretory pore in the anterior third of the body. Vulva preequatorial. The ovejector is directed towards the anterior region. Eggs with single thin shell without operculum. Posterior end of body terminating in straight, stiff tail. Measurements are given in Table 1.

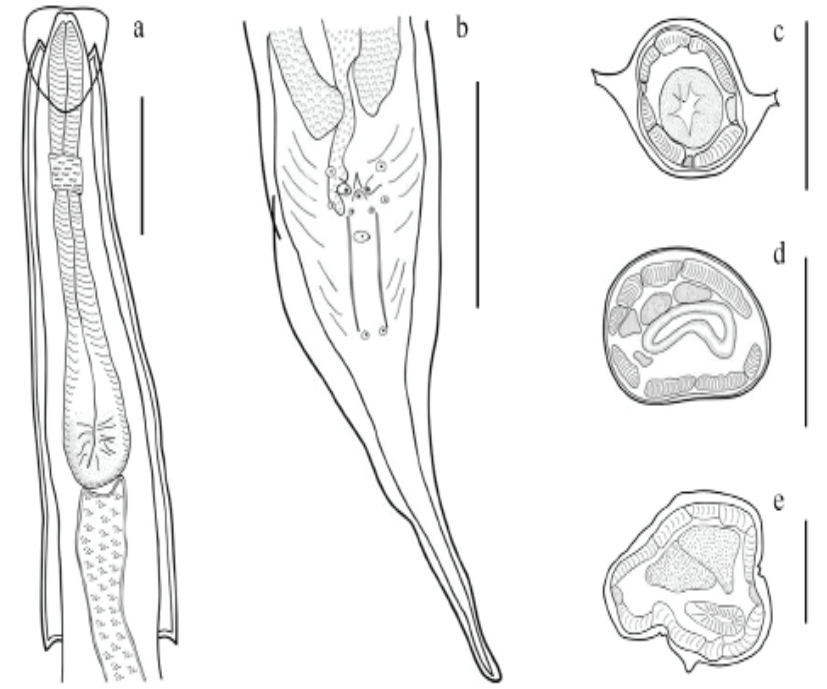

Figure 2: Aspiculuris americana male, a). Anterior end of male, lateral view. b). Detail of posterior end of male, arrangement of caudal papillae. Cross sections c). Mid-cervical alae. d). Mid-body region. e). Precloacal region. Bar $=100 \mu \mathrm{m}$.

\section{Discussion}

The genus Aspiculuris was appointed first as Ascaris to A. tetraptera, later Schulz in 1924 proposed the genus Aspiculuris with the type species A. teraraptera (Skrjabin et al. 1960). Aspiculuris was divided into two groups by Quentin (1975) based on the outline shape of the cervical alae. Members of the first group are characterized by having cervical alae that are abruptly interrupted with the posterior ends pointed and forming an acute angle toward the anterior $A$. tetraptera, A. dinnicki, A. schulzi, A. kazakstanica, A. americana, A. lahorica, A. pakistanica, A. tschertkowi, A. azerbaidjanica, A. arianica, A. rysavyi, A. versterae, A. nainitalensis, A. bengalensis, $A$. huascaensis, A tiajinensis. In the second group, cervical alae gradually decrease its width, joining the wall-body or to the lateral alae if there, $A$. asiatica, A. africana, A. ratti, $A$. witenbergi, and $A$. shikoloveta. These species are distributed in Africa, North America, Asia and Europe, only A. tetraptera has a worldwide distribution (Arya 1980; Hugot 1980; Manna et al. 1985; Liu et al. 2012).

Aspiculuris americana was described by Erickson (1938) as a parasite of Peromyscus maniculatus and P. leucopus in Minnesota. Since then, this taxon has been recorded in several species of Peromyscus from the United States of America (Table 2). Erickson (1938), who do not justify the inclusion of the species in the genus Aspiculuris, only defined it by the following traits, esophagus club-shaped, thinnest immediately anterior to the elongate bulb, cervical alae terminate in a recurved margin a short distance below the level of esophageal bulb. Based on our examination of the new material from $P$. difficilis from México and the description of Erickson (1938), we determinate the following characteristics: cervical alae continuous with lateral alae, short and abruptly interrupted forming an acute angle, esophageal bulb elongate and male with tail long, slender and pointed. We also confirm that the specimens do not have a lateral alae running throughout the body, as mentioned by Akhtar (1955). When comparing the material of México 
with the description of Erickson, we find that he recorded four pairs of papillae in a lateral view, one pair immediately anterior to the anus, three pairs postanal, and one pair away from the anus; we found the same pattern papillary when review our material, however, in ventral view, the specimens collected from $P$. difficilis have 12 papillae, so we consider it a new trait to A. americana. On the other hand, Erickson (1938) described the cervical alae recurved, extending below from junction esophagus-intestine 122 $\mu \mathrm{m}$ in males and 120 to $160 \mu \mathrm{m}$ in females, without considering that cervical alae only refer to the anterior end, there-

Table 1: Measurements of Aspiculuris americana from three species of Peromyscus.

\begin{tabular}{|c|c|c|c|c|}
\hline \multirow{3}{*}{ Host } & \multicolumn{2}{|c|}{ Erickson, 1938} & \multicolumn{2}{|c|}{ This study } \\
\hline & \multicolumn{2}{|c|}{$\begin{array}{l}\text { P. leucopus and } \\
\text { P. maniculatus }\end{array}$} & \multicolumn{2}{|c|}{ P. difficilis } \\
\hline & Male & Female & Male & Female \\
\hline Length (mm) & $2.25-2.46$ & $3.17-3.88$ & $\begin{array}{c}2.40-3.54 \\
(3.26 \pm 0.33 ; n=13)\end{array}$ & $\begin{array}{c}3.55-5.52 \\
(4.48 \pm 0.57 ; n=16)\end{array}$ \\
\hline $\begin{array}{l}\text { Maximum } \\
\text { diameter }\end{array}$ & & & $\begin{array}{c}84-120 \\
(100 \pm 11 ; n=13)\end{array}$ & $\begin{array}{c}138-200 \\
(166 \pm 21 ; n=16)\end{array}$ \\
\hline \multicolumn{5}{|c|}{ Cephalic inflation } \\
\hline Lenght & & & $\begin{array}{c}75-100 \\
(86 \pm 9 ; n=13)\end{array}$ & $\begin{array}{c}75-130 \\
(104 \pm 14 n=17)\end{array}$ \\
\hline Wide & & & $\begin{array}{c}70-95 \text { wide } \\
(80 \pm 7 ; n=13)\end{array}$ & $\begin{array}{c}85-105 \text { wide } \\
(96 \pm 6 ; n=17)\end{array}$ \\
\hline \multicolumn{5}{|c|}{ Esophagus with bulb } \\
\hline Length & 288 & $381-408$ & $\begin{array}{c}315-435 \\
(362 \pm 38 ; n=13)\end{array}$ & $\begin{array}{c}400-525 \\
(447 \pm 43 ; n=15)\end{array}$ \\
\hline \multicolumn{5}{|c|}{ Esophageal bulb } \\
\hline Lenght & 112.5 & & $\begin{array}{c}115-150 \\
(128 \pm 10 ; n=13)\end{array}$ & $\begin{array}{c}125-160 \\
(141 \pm 11 ; n=16)\end{array}$ \\
\hline Wide & 48.5 & 64 & $\begin{array}{c}50-70 \\
(57 \pm 6 ; n=13)\end{array}$ & $\begin{array}{c}56-85 \\
(74 \pm 8 ; n=14)\end{array}$ \\
\hline Nerve ring & & 217 & $\begin{array}{c}94-119 \\
(107 \pm 9 ; n=13)\end{array}$ & $\begin{array}{c}100-175 \\
(132 \pm 17 n=15)\end{array}$ \\
\hline Excretory pore & & & $\begin{array}{c}665-728 \\
(693 \pm 26 ; n=6)\end{array}$ & $\begin{array}{c}835-975 \\
(887 \pm 77 ; n=3)\end{array}$ \\
\hline \multicolumn{5}{|c|}{ Cervical alae and lateral alae } \\
\hline Beginning & & & $\begin{array}{c}34-44 \\
(38 \pm 5 ; n=6)\end{array}$ & $\begin{array}{c}31-54 \\
(41 \pm 8 ; n=12)\end{array}$ \\
\hline Lenght & & & $\begin{array}{c}415-575 \\
(490 \pm 44 ; n=11)\end{array}$ & $\begin{array}{c}470-454 \\
(504 \pm 20 ; n=12)\end{array}$ \\
\hline \multicolumn{5}{|c|}{ Lateral alae } \\
\hline Lenght & 122 & $120-160$ & $\begin{array}{c}100-228 \\
(145 \pm 42 ; n=10)\end{array}$ & $\begin{array}{c}81-213 \\
(119 \pm 35 ; n=11)\end{array}$ \\
\hline \multicolumn{5}{|c|}{ Caudal alae } \\
\hline Lenght & & & $\begin{array}{c}100-169 \\
(124 \pm 22 ; n=11)\end{array}$ & \\
\hline Vulva (mm) & & $1.25-1.45$ & & $\begin{array}{c}1.632-2.200 \\
(1.859 \pm 0.166 ; n=9)\end{array}$ \\
\hline Ovejector & & & & $\begin{array}{c}106-156 \\
(132 \pm 21 ; n=5)\end{array}$ \\
\hline Anus & & $656-741$ & $\begin{array}{c}210-265 \\
(241 \pm 17 ; n=13)\end{array}$ & $\begin{array}{c}850-950 \\
(892 \pm 52 ; n=3)\end{array}$ \\
\hline \multicolumn{5}{|c|}{ Eggs } \\
\hline Lenght & & $76-83$ & & $\begin{array}{c}69-85 \\
(79 \pm 5 ; n=17)\end{array}$ \\
\hline Wide & & $27-35$ & & $\begin{array}{c}25-41 \\
(32 \pm 3 ; n=17)\end{array}$ \\
\hline
\end{tabular}

Table 2: Current distribution of Aspiculuris americana.

\begin{tabular}{|c|c|c|}
\hline Host & Locality & Reference \\
\hline Peromyscus gossypinus & $\begin{array}{l}12 \mathrm{~km} \text { south of Lake Placid, } \\
\text { Highlands Co., Florida }\end{array}$ & Kinsella 1991 \\
\hline \multirow[t]{6}{*}{ P. leucopus } & Allegany Co., Maryland & Lichtenfels and Haley 1968 \\
\hline & St. Paul, Minnesota & $\begin{array}{l}\text { Erickson 1938; HWML:Para: } \\
21838,21839\end{array}$ \\
\hline & Pennsylvania & Behnke 2015 \\
\hline & $\begin{array}{l}\text { Mountain Lake Biological } \\
\text { Station, Virginia }\end{array}$ & Walsh 2013 \\
\hline & $\begin{array}{l}\text { Pembroke, Mountain Lake } \\
\text { Biological Station, Virginia }\end{array}$ & USNM 1365217 \\
\hline & Virginia & USNM 1365205 \\
\hline \multirow[t]{7}{*}{ P. maniculatus } & Pine Co., Minnesota & Erickson 1938 \\
\hline & Minnesota & $\begin{array}{l}\text { HWML: 21851, 21852, 21865, } \\
21866,21877,21901,21902\end{array}$ \\
\hline & Deuel, Co., Nebraska & USNM 1371217 \\
\hline & Nebraska & HWML: 31648,37276 \\
\hline & $\begin{array}{l}\text { Great Basin Desert, Juab } \\
\text { County, Utah }\end{array}$ & USNM 1397713 \\
\hline & $\begin{array}{l}\text { Mountain Lake Biological } \\
\text { Station, Virginia Virginia }\end{array}$ & Walsh 2013 \\
\hline & $\begin{array}{l}1 / 4 \text { mi W Lake LaBerge, } \\
\text { Yukon Territory, Canada. }\end{array}$ & MSB:24831 \\
\hline Peromyscus sp. & $\begin{array}{l}\text { Burns Road, Whitehorse, } \\
\text { Yukon Territory, Canada }\end{array}$ & MSB: 24847 \\
\hline \multirow[t]{2}{*}{ Podomys floridanus } & $\begin{array}{l}12 \mathrm{~km} \text { south of Lake Placid, } \\
\text { Highlands Co., Florida } \\
\text { Florida }\end{array}$ & Kinsella 1991 \\
\hline & 7 and $10 \mathrm{mi} \mathrm{NW}$ Gainesville & USNM: 1353396, 1353399 \\
\hline
\end{tabular}

HWML: Harold W. Manter Laboratory of Parasitology; MSB: Museum of Southwestern Biology; USNM: United States National Museum.

fore, these measures correspond to the lateral alae; while in the Mexican specimens the lateral alae extending of the junction esophagus-intestine 100 to 228 and 81 to 213 in male and female respectively.

Our research suggests that $A$. americana is an oioxenus and monoxenus parasite of rodents of the genus Peromyscus with six species parasitized (Table 2), which would also show that the host-parasite relationship is ancestral, according to host phylogenetic (Bradley et al. 2007). Finally, the present study provides the first report of $A$. americana in an endemic rodent from México, expanding the known distribution range of the species south of the country.

\section{Acknowledgements}

We are grateful to Berenit Mendoza-Garfias for her assistance in processing samples for SEM microphotographs and Luis García-Prieto for the loan of specimens from the Colección Nacional de Helmintos, Universidad Nacuinal Autónoma de México.

\section{Literature cited}

AkHTAR, S. A. 1955. On nematode parasites of rats and mice of Lahore, with some remarks on the genus Aspiculuris Schulz, 1924 and two news species of the genus. Pakistan Journal of Scientific Research 7:104-111. 
ArYa, S. N. 1980. A new species of the genus Aspiculuris (Nitzsch, 1821) Schulz, 1924 from the common house rat, Rattus rattus of Nainital, India (Nematoda). Revista Brasileira de Biologia 4:747-749.

Behnke, J. M., A. Stewart, A. Bajer, M. Grzybeck, P. D. Harris, A. Lowe, A. Ribas, L. Smales, and K. J. Vandergrift. 2015. Bank voles (Myodes plareolus) and house mice (Mus musculus; M. m. domesticus) in Europe are each parasitized by their own distinct species of Aspiculuris (Nematoda, Oxyurida). Parasitology 142:1493-1505.

Bradley, R. D., N. D. Durish, D. S. Rogers, J. R. Miller, M. D. Engstrom, AND W. KILPATRICK. 2007. Toward a molecular phylogeny for Peromyscus: evidence from mitochondrial cytochrome-b sequences. Journal of Mammalogy 88:1146-1159.

ERICKSON, A. B. 1938. Parasites of some Minnesota Cricetidae and Zapodidae and a host catalogue of helminth parasites of native American mice. American Midland Naturalist 20:575-589.

Falcón-Ordaz, J., S. Monks, G. Pulido-Flores, L. García-Prieto, and G. Lira-Guerrero. 2015. Riqueza de helmintos parásitos de vertebrados silvestres del estado de Hidalgo, México. Pp. 2037 in Estudios en Biodiversidad Volumen I. (Pulido-Flores, G., S. Monks y M. López-Herrera, eds.). Zea Books. Lincoln, U. S. A.

Fernández, J. A., F. García-Campusano, and M. S. Hafner. 2010. Peromyscus difficilis (Rodentia, Cricetidae). Mammalian Species 42:220-229.

García-Prieto, L., J. Falcón-Ordaz, and C. Guzmán-Cornejo. 2012. Helminth parasites of wild mexican mammals: list of species, hosts and geographical distribution. Zootaxa 3290:1-92.

Goswami, U., A. Chaudhary, C. Verma, and H. S. Singh. 2015. First molecular characterization of Aspiculuris tetraptera (Nematoda: Heteroxynematidae) from Mus musculus (Rodentia: Muridae) in India. Acta Parasitologica 60:553-556.

Hugot, J. P. 1980. Sur le genre Aspiculuris Schulz, 1924 (Nematoda, Heteroxynematidae), Oxyures parasites de Rongeurs Muroidea. Bulletin du Museum National d'Histoire Naturelle, Paris 2:723-735.

Kelt, D. A., M. S. Hafner, and the American Society of Mammalogists'ad HOC COMMITTEE FOR GUIDELINES ON HANDLING RODENTS IN THE FIELD. 2010. Updated guidelines for protection of mammalogists and wildlife researchers from hantavirus pulmonary syndrome (hps). Journal of Mammalogy 91:1524-1527.

KINSELLA, J. M. 1991. Comparison of helminthes of three species of mice, Podomys floridanus, Peromyscus gossypinus, and Peromyscus polionotus, from southern Florida. Canadian Journal of Zoology 59:3078-3083.

LiChtenfels, J. R., AND A. J. Haley. 1968. New host records of intestinal nematodes of Maryland rodents and suppression of Capillaria bonnevillei Grundman and Frandsen, 1960 as a synonym of C. americana Read, 1949. Proceedings of the Helminthological Society of Washington 35:206-211.

LiU, B., Y. Bu., AND L. ZhANG. 2012. A new species of Aspiculuris Schulz, 1924 (Nematoda, Heteroxynematidae) from the graysided vole, Clethrionomys rufocanus (Rodentia, Cricetidae), from Tianjin, China. Acta Parasitologica 57:311-315.

Manna, B., C. Date, and S. Dey. 1985. On a new species of the genus (Aspicularis paraspicularis) from white mice Mus musculus. Indian Animal Health 24:1-3.

Quentin, J. C. 1975. Essai de classification des Oxyures Heteroxynematidae. Memoires du Museum National d' Histoire Naturelle, Zoologie 94:51-96.
Sikes, R. S., AND The ANimal CARE AND USE COMmittee of the American Society of MAmmalogists. 2016. Guidelines of the American Society of Mammalogists for the use of wild mammals in research and educaation. Journal of Mammalogy 97:663-688.

Skrjabin, K. I., N. P. Schikhobalova, and E. A. Lagodovskaja. 1960. Oxyurata of Animals and Man. Part one. Oxyuroidea. Izdatel'stvo Akademii Nauk SSSR, Moskva. Translated from Russian, Israel Program for Scientific Translation, Jerusalem, Israel.

Walsh, P. T., E. McCreless, and A. B. Pedersen. 2013. Faecal acoidance and selective foraging: do wild mice have the luxury to avoid faeces? Animal Behaviour 86:559-566.

Associated editor: Jesús Fernández

Submitted: December 3, 2018; Reviewed: March 4, 2019;

Accepted:April 1, 2019; Published on line:April 4, 2019. 